\title{
Study of Environmental Accounting Information Disclosure and Financial Performance of Heavy Pollution Enterprises - Based on Empirical Evidence of Coal Enterprises
}

\author{
Cailing $\mathrm{Xu}^{1, *}$ \\ ${ }^{1}$ Xinhua College of Sun Yat-sen University, Guangzhou, Guangdong 510520, China \\ *Corresponding author. Email: Cailingxuzhong@163.com
}

\begin{abstract}
At present, China's economic and technological development is obvious to all but environmental problems are increasingly serious. As a strong supporter of economic development, enterprises should take corresponding responsibility for environmental protection when pursuing economic benefits. Therefore, it is of great significance to study the relationship between environmental accounting information and financial performance of enterprises. Based on the relevant data of coal listed companies from 2016 to 2018, this paper empirically analyzes the relationship between environmental accounting information disclosure and financial performance of coal industry. The results show that the environmental accounting information disclosure of the coal industry has a positive correlation with profitability and development ability, but not with debt level. The research not only enriches the content of environmental accounting information disclosure, but also helps heavy pollution enterprises to make decisions based on financial performance; and it also provides empirical basis for the society and government departments to establish a standard and perfect environmental information disclosure system.
\end{abstract}

\section{Keywords: environmental accounting information, coal industry, financial performance}

\section{INTRODUCTION}

Among the rich natural resources on the earth, coal resource reserves are high and its demand is huge. It is the main energy in China's energy consumption structure. In 2018, according to the Bulletin on China's Ecological Environment issued by the Ministry of Ecological Environment, 121 cities in China met the standard of ambient air quality, accounting for $35.8 \%$ of all cities; and 217 cities exceeded the standard, accounting for $64.2 \%$. Therefore, ecological civilization, sustainable development and other topics are widely concerned by the whole society. A series of policies and regulations on environmental protection issued by domestic and foreign governments have aroused the attention of enterprise managers to environmental information disclosure. Foreign countries began to pay attention to environmental accounting information much earlier. Their laws and regulations of environmental accounting information disclosure are also relatively comprehensive. For example, the Act on Clean Water Source of the United States requires enterprises to fully disclose the quality information of surrounding water resources. China started late and has not yet entered the stage of legislation to compel enterprises to fully disclose environmental accounting information and form a perfect legal system. In recent years, more attention has been paid to the regulation of environmental accounting information disclosure in China, such as mandatory disclosure of relevant environmental information for enterprises with serious environmental pollution, and the implementation of the Measures for Environmental Information Disclosure of Enterprises and Institutions, which encourages other types of enterprises to voluntarily disclose the information. In 2010, in the Guidelines for Environmental Information Disclosure of Listed Companies, the Ministry of Environmental Protection clearly pointed out that 16 industries including thermal power, iron and steel, cement, electrolytic aluminum, coal, metallurgy, chemical industry, petrochemical, building materials, paper-making, brewing, pharmaceutical, fermentation, textile, tanning and mining industries are heavy polluting industries. Such listed companies should issue annual environmental reports to regularly disclose environmental information, such as pollutant discharge, environmental compliance, environmental management and etc. 
In 2018, with the implementation of the Law of Environmental Protection Tax and the introduction of environmental protection tax, enterprises must practically concern the environmental construction. For coal listed companies (hereinafter referred to as coal enterprises) have high production capacity, large output and serious pollution discharge, which seriously affect the quality of air, water and land resource. Their disclosure of environmental information is very important. However, the quantity and quality of environmental accounting information disclosure of listed companies in coal industry have been worrying for many years. During their operation, the business results impact the environment so the related research topics have emerged. Scholars at home and abroad have done a lot of empirical research on environmental accounting information disclosure. But specific conclusions on the relevance of environmental accounting information disclosure and value have not yet formed. Based on this, the paper studies the relationship between environmental accounting information disclosure and financial performance of coal enterprises. The research not only enriches the content of environmental accounting information, but also helps heavy pollution enterprises to make decisions based on financial performance, and also provides empirical basis for the society and government departments to establish a standard and perfect disclosure system.

\section{THEORETICAL ANALYSIS AND RESEARCH HYPOTHESIS}

According to stakeholder theory, the disclosure of environmental accounting information will be used by stakeholders especially investors, and plays a key role in major decisions. Foreign studies have confirmed that there is a positive correlation between environmental accounting information disclosure and stock value [2]; it improves enterprise value [3]; and its level has a positive correlation with financial performance [4][5]. In addition, government regulations effectively improve its quality and alleviates problems of information asymmetry. Therefore, they are easier to obtain more investment capital from investors to improve enterprise value [6]. Through research, domestic scholars have concluded that carbon information has a positive effect on financial performance [7] [8] and there is a positive correlation between environmental information disclosure and financial performance [9][10][11]. For listed companies in heavy pollution industries, empirical results show that high-quality environmental information disclosure can alleviate debt repayment and financing pressure, reduce financing costs and significantly improve enterprise value [12]; environmental accounting information disclosure of pollution intensive enterprises has a positive effect on their performance [13].
In order to maximize shareholders' equity, listed companies will actively disclose environmental accounting information to establish a good corporate image so as to attract more cooperation and investment, which will surely improve their profitability. With higher profit, their investment in environmental protection will increase, and so their willingness of information disclosure will be more active. So, the level of environmental information disclosure has a significant positive correlation with the return on net assets [14] [8]. Based on this, the following hypothesis is put forward:

Hypothesis 1: There is a positive correlation between the level of environmental accounting information disclosure and their profitability.

The purpose of information disclosure of listed companies is to provide investors with more equal and accurate information. With proper use of debt, enterprises can benefit from financial leverage. If a enterprise's debt is high, creditors will face greater financial risk. In order to reduce creditors' worries caused by excessive financial risks, enterprises will actively disclose more information and avoid the increase of interest rates, which creditors often use to protect their interests. Scholars have shown that there is a positive correlation between environmental information disclosure and debt ratio [8].The cross item of environmental information disclosure and the asset liability ratio at the level of $1 \%$ has a significant positive correlation with enterprise value; and for heavy pollution enterprises, the asset liability ratio is positively correlated with the enterprise environmental information disclosure level [16]. Therefore, enterprises' solvency is positively correlated to their environmental accounting information disclosure [17]; and the debt degree of listed companies has a significant impact on their environmental information disclosure [18]. Based on this, the following hypothesis is put forward:

Hypothesis 2: There is a positive correlation between environmental information disclosure level and debt level.

According to stakeholder theory and signal transmission theory, if enterprises show a positive attitude, transmit a better signal of responsibility to the society, disclose high-quality environmental accounting information and establish a positive image to the stakeholders and the society, they can obtain government's subsidies on environmental protection, tax deduction and other policy preferences [15],which is conducive for the them to expand their scale and get more development potential. Meanwhile, with more concern on the environmental protection problem from the whole society, they can also obtain more social recognition and larger market share so as to have better development competitiveness. Listed companies in 
heavy pollution industries have been long established. In order to maintain the public interest demands for their environmental protection and a good image, they need to constantly maintain the increasing costs of environmental protection and governance and thus require high-speed growth of business income [19]. Scholars' research results show that there is an important relationship between enterprise's growth ability and its environmental information [20]; the level of environmental information disclosure has a significant positive correlation with the growth rate of operating profit [14]. Based on this, the following hypothesis is put forward:

Hypothesis 3: There is a positive correlation between the level of environmental accounting information disclosure and its development ability.

\section{RESEARCH DESIGN}

\section{A. Sample selection and data sources}

The paper selects data of listed companies in coal industry from 2016 to 2018 as the research object, from the IFind database of Tonghuashun. Excluding ST and * ST listed companies and those companies with incomplete financial data, finally 69 samples are obtained to study the relationship between environmental accounting disclosure and financial performance. Statistical analysis software SPSS.21 is used to obtain relevant data in the process of empirical research.

\section{B. Definition of variables}

1) Definition of dependent variables: Financial performance is a result that can be used to evaluate business performance after analyzing various factors such as enterprise profitability, debt risk and business growth. The paper measures the financial performance of enterprises from the following dimensions: profitability, debt level and development ability. The indicators in "Table I" are selected as the dependent variables.

TABLE I. DEFINITION OF DEPENDENT VARIABLES

\begin{tabular}{c|l|l}
\hline $\begin{array}{c}\text { S/ } \\
\mathbf{N}\end{array}$ & \multicolumn{1}{|c|}{ Index } & \multicolumn{1}{c}{ Impact on Financial Performance } \\
\hline 1 & $\begin{array}{l}\text { Return on net } \\
\text { assets }\end{array}$ & $\begin{array}{l}\text { the higher the value, the stronger the } \\
\text { ability of enterprise to obtain profits }\end{array}$ \\
\hline 2 & $\begin{array}{l}\text { Asset liability } \\
\text { ratio }\end{array}$ & $\begin{array}{l}\text { the lower the value, the lower the debt } \\
\text { risk and the stronger the long-term } \\
\text { solvency of the enterprise }\end{array}$ \\
\hline 3 & $\begin{array}{l}\text { Growth rate } \\
\text { of operating } \\
\text { revenue }\end{array}$ & $\begin{array}{l}\text { the higher the value, the stronger the } \\
\text { development ability of the enterprise } \\
\text { in the future }\end{array}$ \\
\hline
\end{tabular}

2) Definition of independent variables: At present, there is no systematic requirement for environmental information disclosure in China. For enterprises, there is no perfect system to stipulate how to disclose the content of environment. In the paper, the quality standard of environmental accounting information disclosure of enterprises is formulated based on relevant literature and guidelines. With reference to the Measures of Environmental Information Disclosure and Guidelines of Environmental Information for Listed Companies and the main environmental information required to be disclosed in Article 44 of Document No. 17 issued by China Securities Regulatory Commission in 2017, the following disclosure items are sorted out and their scoring standards are set in "Table II". The higher the score, the higher the quality of environmental accounting information disclosure is. For the sake of research and comparison, the enterprise environmental accounting information level is expressed by the environmental information disclosure index EDI, defined as the ratio of the sample enterprise score and the total score (17 points) of the disclosure items.

TABLE II. ITERMS OF ENVIRONMENTAL ACCOUNTING INFORMATION DISCLOSURE AND SCORING STANDARDS

\begin{tabular}{|c|c|c|}
\hline $\mathbf{S} / \mathbf{N}$ & Items & Scoring Standards \\
\hline 1 & environmental protection policy and concept & \multirow{3}{*}{$\begin{array}{l}1 \text { point for disclosure, } \\
0 \text { for no disclosure }\end{array}$} \\
\hline 2 & $\begin{array}{l}\text { with separate environmental reports (social responsibility reports) } \\
\text { or not? }\end{array}$ & \\
\hline 3 & with emergency plans for environmental emergencies or not? & \\
\hline 4 & investment in environmental protection & \multirow{7}{*}{$\begin{array}{l}2 \text { points for } \\
\text { quantitative } \\
\text { disclosure, } \\
1 \text { point for qualitative } \\
\text { disclosure, } \\
0 \text { for no disclosure }\end{array}$} \\
\hline 5 & pollutant discharge & \\
\hline 6 & waste treatment and recycling & \\
\hline 7 & construction and operation of environmental protection facilities & \\
\hline 8 & payment of sewage charges, etc. & \\
\hline 9 & energy conservation, emissions reduction & \\
\hline 10 & reward, subsidy and tax relief on environmental protection & \\
\hline
\end{tabular}

3) Definition of control variables: Based on the principle of preciseness, various factors and differences in the size and governance structure of different enterprises and considered. Enterprise's scale affects its 
influence and the ability to withstand external pressure, which has a certain impact on its financial performance. The proportion of non tradable shares is the proportion of the share capital of the total share capital after removing the restricted shares. Generally, the larger the proportion of tradable shares, the better the financial performance is. Independent directors are composed of directors who have no interest relationship with the company. They play the role of supervision and warning to the management of the company. Due to the independence of their identity, the higher proportion of independent directors, the greater the role of supervision of the company is and the more constructive opinions on the company's decisionmaking. In some degree, it affects the level of an enterprise's financial performance. Therefore, the above-mentioned three factors are set as control variables to accurately analyze the relationship between environmental accounting information disclosure and financial performance. The specific variables are defined in "Table III".

TABLE III. DEFINITION OF CONTROL VARIABLES

\begin{tabular}{c|l|c|l}
\hline \multicolumn{1}{c|}{ Type of Variables } & \multicolumn{1}{|c|}{ Name of Variables } & Code & \multicolumn{1}{c}{ Definition of Variables } \\
\hline \multirow{4}{*}{ Dependent variables } & Return on net assets & $\mathrm{Y}_{1}$ & $\begin{array}{l}\text { net profit/average } \\
\text { net assets }\end{array}$ \\
\cline { 2 - 4 } & Asset liability ratio & $\mathrm{Y}_{2}$ & total liabilities/total assets \\
\cline { 2 - 4 } & $\begin{array}{l}\text { Growth rate of operating } \\
\text { revenue }\end{array}$ & $\mathrm{Y}_{3}$ & $\begin{array}{l}\text { (operating income of the current period - business income of the } \\
\text { previous period) /operating income of the previous period }\end{array}$ \\
\hline \multirow{2}{*}{ Independent variables } & $\begin{array}{l}\text { Environmental accounting } \\
\text { information disclosure index }\end{array}$ & EDI & score of disclosure quality/total score of disclosure items \\
\hline \multirow{2}{*}{ Control variables } & Enterprise scale & SIZE & natural logarithm of total assets at the end of the period \\
\cline { 2 - 4 } & Proportion of tradable shares & CS & number of non-tradable shares/total capital stock \\
\cline { 2 - 4 } & $\begin{array}{l}\text { Proportion of independent } \\
\text { directors }\end{array}$ & INDR & number of independent directors/total number of directors \\
\hline
\end{tabular}

\section{Model design}

In order to verify the correctness of the above hypotheses, the following models are built for the regression analysis on the above three hypotheses.

$$
\begin{gathered}
Y i=b_{0}+b_{1} E D I+b_{2} S I Z E \\
+b_{3} C S+b_{4} I N D R+\varpi_{i, t}
\end{gathered}
$$

\section{EMPIRICAL ANALYSIS}

\section{A. Descriptive Statistics analysis}

Descriptive analysis is done by software SPSS 21. The statistical results are shown in "Table IV".

\begin{tabular}{|c|c|c|c|c|c|}
\hline Items & $\mathbf{N}$ & $\begin{array}{c}\text { Minimum } \\
\text { Value }\end{array}$ & Maximum Value & $\begin{array}{l}\text { Mean } \\
\text { Value } \\
\end{array}$ & Standard Deviation \\
\hline $\mathrm{Y}_{1}$ & 69 & 0.274 & 25.264 & 8.549 & 5.663 \\
\hline $\mathrm{Y}_{2}$ & 69 & 26.216 & 75.608 & 52.956 & 13.415 \\
\hline $\mathrm{Y}_{3}$ & 69 & -9.728 & 72.413 & 23.106 & 21.336 \\
\hline $\begin{array}{l}\text { Score of environmental accounting information } \\
\text { disclosure } \\
\end{array}$ & 69 & 1.000 & 16.000 & 10.800 & 3.681 \\
\hline EDI & 69 & 0.059 & 0.941 & 0.635 & 0.217 \\
\hline $\mathrm{CS}$ & 69 & 0.085 & 1.000 & 0.823 & 0.258 \\
\hline SIZE & 69 & 22.922 & 27.099 & 24.310 & 1.124 \\
\hline INDR & 69 & 0.231 & 0.500 & 0.347 & 0.044 \\
\hline Number of effective cases (listed) & 69 & & & & \\
\hline
\end{tabular}

TABLE IV. DESCRIPTIVE STATISTICS RESULTS

From "Table IV", it is known that the standard deviations of sample enterprises' financial performance indicators, e.g. rate of return, asset liability ratio and growth rate of operating revenue are 5.663, 13.415 and 
21.336 respectively. It indicates that the sample enterprises have a large gap in profitability, solvency and development ability. It provides a certain reference for the research of the relationship between environmental disclosure index and financial performance. In terms of the score of environmental accounting information disclosure, the average score of sample enterprises is 10.8, at medium level. The standard deviation is 3.681 , showing that the environmental accounting information disclosure of China's coal industry is at medium level as a whole and there are obvious gaps between enterprises. There is still room for enterprises to improve their awareness of environmental accounting information disclosure. The maximum value of EDI is 0.941 and the minimum value is 0.059 , which indicates that the gap of disclosure quality is relatively large, reflecting the low degree of restriction of relevant regulations on enterprises. From the results of the proportion of tradable shares and enterprise scale, the fluctuation between the sample data is small, showing that the gap between the operating scale and the proportion of tradable shares is small. The average proportion of independent directors is 0.347 , majorly meeting the one-third requirement of independent directors, which reflects that the enterprise structure is more perfect and the decision-making is more reliable.

\section{B. Coorrelation analysis}

Through the verification of the correlation among the variables of the model, research results are shown in "Table V".

In statistics, when the correlation coefficient between variables is more than 0.5 , it is generally considered that there may be multicollinearity, while when the correlation coefficient is more than 0.8 , there may be serious multicollinearity. If regression analysis is still carried out, the reliability of the conclusion may be affected. "Table V" shows that the correlation coefficient of each variable is below 0.5 , which proves that there is no significant collinearity between them. Therefore, regression analysis can be applied to the above design model.

TABLE V. CORRELATION COEFFICIENT AMONG VARIABLES

\begin{tabular}{c|c|c|c|c|c|c|c}
\hline Variables & $\mathbf{Y}_{\mathbf{1}}$ & $\mathbf{Y}_{\mathbf{2}}$ & $\mathbf{Y}_{\mathbf{3}}$ & $\mathbf{E D I}$ & $\mathbf{C S}$ & $\mathbf{S I Z E}$ & $\mathbf{I N D R}$ \\
\hline $\mathrm{Y}_{1}$ & 1.00 & -0.28 & 0.17 & 0.39 & -0.02 & 0.11 & 0.13 \\
\hline $\mathrm{Y}_{2}$ & -0.28 & 1.00 & 0.08 & -0.08 & -0.03 & 0.21 & -0.11 \\
\hline $\mathrm{Y}_{3}$ & 0.17 & 0.08 & 1.00 & 0.21 & -0.14 & 0.03 & 0.01 \\
\hline EDI & 0.39 & -0.08 & 0.21 & 1.00 & 0.22 & 0.27 & -0.03 \\
\hline $\mathrm{CS}$ & -0.02 & -0.03 & -0.14 & 0.22 & 1.00 & 0.23 & 0.15 \\
\hline SIZE & 0.11 & 0.21 & 0.03 & 0.27 & 0.23 & 1.00 & 0.46 \\
\hline INDR & 0.13 & -0.11 & 0.01 & -0.03 & 0.15 & 0.46 & 1.00 \\
\hline
\end{tabular}

\section{Rgegression analysis}

In regression analysis of the return on net assets of dependent variable $Y_{1}$, the coefficient of EDI is 11.538, $\mathrm{T}$ value is 3.661, absolute value greater than 1.96, indicating that independent variable EDI has influence on the equation; and significance is 0.001 , less than 0.05 , passing significance test. Therefore, there is a positive correlation between enterprise profitability and environmental accounting information disclosure and Hypothesis 1 holds. It shows that the company with strong profitability is more able to undertake social responsibility and disclose high-quality environmental accounting information; meanwhile, environmental accounting information disclosure helps enterprises to establish positive image and to get the trust from stakeholders, so as to attract more investment and then to improve their profitability.

In regression analysis of asset liability ratio of the dependent variable $\mathrm{Y}_{2}$, the coefficient of EDI is -11.428; $\mathrm{T}$ value is -1.476 ; absolute value is less than 1.96 and the significance is 0.145 , greater than 0.05 , which fails to pass the significance test. It indicates that there is no correlation between the solvency of coal enterprises and environmental accounting information disclosure. Therefore, Hypothesis 2 is not tenable. This is probably related to the fact that outsiders pay more attention to the future value of the industry and that most coal enterprises are state-owned holding companies. Enterprises with high debt level can be more trusted and can benefit from financial leverage. In risk aversion measures, it is less considered to adjust the disclosure quality of environmental accounting information.

In regression analysis of operating income growth rate of dependent variable $\mathrm{Y}_{3}$, the coefficient of EDI is 25.841; $\mathrm{T}$ value is 2.041 and the absolute value is greater than 1.96, which indicates that the independent variable of EDI has an influence on the equation; and the significance is 0.045 , less than 0.05 . Through the significance test, we can see that there is a positive correlation between enterprise development ability and environmental accounting information disclosure index. 
Therefore, Hypothesis 3 is tenable. As heavy pollution industry, coal listed companies have been long established. In order to maintain their good public image, they need to maintain the cost of environmental protection and governance, and transmit a good signal of responsibility to the society. Therefore, they need high-speed business income growth.
$\mathrm{R}^{2}$ in "Table VI" is used to study the goodness-of-fit. Referring to the empirical analysis of similar research literature, most scholars consider that $\mathrm{R}^{2}$ in the abovementioned statistical results is not high but explanatory. Therefore, the paper considers that the goodness-of-fit of the model is acceptable.

TABLE VI. LINEAR REGRESSION ANALYSIS

\begin{tabular}{|c|c|c|c|c|c|c|}
\hline \multirow{2}{*}{ Items } & \multicolumn{2}{|c|}{$\mathrm{Y}_{1}$} & \multicolumn{2}{|c|}{$\mathbf{Y}_{2}$} & \multicolumn{2}{|c|}{$\mathbf{Y}_{3}$} \\
\hline & Co-efficient b & P Value (T) & Co-efficient b & P Value (T) & Co-efficient b & P Value (T) \\
\hline $\begin{array}{l}\text { Con- } \\
\text { stant }\end{array}$ & 3.753 & $\begin{array}{r}0.790 \\
(0.267)\end{array}$ & -24.813 & $\begin{array}{r}0.475 \\
(-0.719)\end{array}$ & 21.540 & $\begin{array}{r}0.704 \\
(0.382)\end{array}$ \\
\hline EDI & 11.538 & $\begin{array}{r}0.001 * * * \\
(3.661)\end{array}$ & -11.428 & $\begin{array}{r}0.145 \\
(-1.476) \\
\end{array}$ & 25.841 & $\begin{array}{r}0.045^{* *} * \\
(2.041)\end{array}$ \\
\hline CS & -2.888 & $\begin{array}{r}0.266 \\
(-1.123)\end{array}$ & -1.776 & $\begin{array}{r}0.780 \\
(-0.281)\end{array}$ & -16.296 & $\begin{array}{r}0.120 \\
(-1.577)\end{array}$ \\
\hline SIZE & -0.373 & $\begin{array}{r}0.584 \\
(-0.551) \\
\end{array}$ & 4.820 & $\begin{array}{r}0.005 * * * \\
(2.898) \\
\end{array}$ & -0.454 & $\begin{array}{r}0.868 \\
(-0.167) \\
\end{array}$ \\
\hline INDR & 25.703 & $\begin{array}{r}0.124 \\
(1.559) \\
\end{array}$ & -88.482 & $\begin{array}{l}0.033 * * \\
(-2.185) \\
\end{array}$ & 27.701 & $\begin{array}{r}0.677 \\
(0.418) \\
\end{array}$ \\
\hline $\mathrm{F}$ & \multicolumn{2}{|c|}{3.810} & \multicolumn{2}{|c|}{2.419} & \multicolumn{2}{|c|}{1.431} \\
\hline $\mathrm{R}^{2}$ & \multicolumn{2}{|c|}{0.192} & \multicolumn{2}{|c|}{0.131} & \multicolumn{2}{|c|}{0.082} \\
\hline $\mathrm{N}$ & \multicolumn{2}{|c|}{69} & \multicolumn{2}{|c|}{69} & \multicolumn{2}{|c|}{69} \\
\hline
\end{tabular}

\section{Robustness test}

The paper uses random sampling method to test the robustness of the empirical results. The random sampling sample is an half of the whole. Taking the return on net assets $Y_{1}$ as dependent variable, regression analysis is conducted on 34 samples. The results are shown in "Table VII". Coefficient EDI is 15.850 and significance is 0.002 , less than 0.05 , passing significance test; $\mathrm{T}$ value is 3.410 and absolute value is greater than 1.96, which indicating that the independent variable EDI has influence on the equation, It shows that there is a positive correlation between environmental accounting information disclosure quality and profitability, consistent with previous conclusions, indicating that the regression analysis results have good robustness.

TABLE VII. RESULTS OF ROBUSTNESS TEST OF RANDOM SAMPLING

\begin{tabular}{c|c|c}
\hline \multirow{2}{*}{ Items } & \multicolumn{2}{|c}{$\mathbf{Y}_{\mathbf{1}}$} \\
\cline { 2 - 3 } & Coefficient b & $\begin{array}{c}\text { Value P } \\
(\text { Value T) }\end{array}$ \\
\hline Constant & 4.170 & $\begin{array}{c}0.829 \\
(0.217)\end{array}$ \\
\hline EDI & 15.850 & $\begin{array}{c}0.002^{* * * *} \\
(3.410)\end{array}$ \\
\hline CS & -3.246 & $\begin{array}{c}0.275 \\
(-1.114)\end{array}$ \\
\hline SIZE & -0.462 & 0.646 \\
\hline
\end{tabular}

\begin{tabular}{c|c|c}
\hline \multirow{2}{*}{ Items } & \multicolumn{2}{|c}{$\mathbf{Y}_{\mathbf{1}}$} \\
\cline { 2 - 3 } & Coefficient b & $\begin{array}{c}\text { Value P } \\
\text { (Value T) }\end{array}$ \\
\hline & & \multicolumn{2}{c}{$(-0.465)$} \\
\hline INDR & 29.989 & $\begin{array}{c}0.181 \\
(1.372)\end{array}$ \\
\hline $\mathrm{F}$ & \multicolumn{2}{|c}{3.946} \\
\hline $\mathrm{R}^{2}$ & \multicolumn{2}{|c}{0.352} \\
\hline $\mathrm{N}$ & \multicolumn{2}{|c}{34} \\
\hline
\end{tabular}

\section{CONCLUSIONS AND SUGGESTIONS}

\section{A. Conclusions}

The paper studies the relationship between environmental accounting information disclosure level and financial performance of listed companies in coal industry and has the following conclusions:

- There is a positive correlation between environmental accounting information disclosure level and profitability of listed companies in China's coal industry. As heavy pollution enterprises, they are forced by the state to disclose environmental accounting information. Enterprises, disclosing high-quality environmental accounting information show their corporate responsibility and obtain subsidies and preferential tax policies for environmental protection from the government, 
as well as have lower financing costs, so as to improve their profitability.

- The relationship between environmental accounting information disclosure level and debt level is not significant. It may be related to the fact that most coal listed companies are stateowned enterprises. When debt level is high, it can play a role of financial leverage, ignoring its impact on the quality of environmental accounting information disclosure.

- There is a positive correlation between environmental accounting information disclosure level and development ability. With the increasing attention to the ecological environment problems of the whole society, enterprises are more active in environmental information disclosure and establish a good corporate image, which is conducive for their scale expansion and higher market share.

\section{B. Suggestions}

In order to better promote the environmental accounting information disclosure and improve the financial performance of heavy pollution enterprises, suggestions are as follows:

- From the perspectives of government: government must improve the environmental accounting information disclosure policy systems, and provide policy guidance and legal basis for environmental accounting of coal and other heavy pollution enterprises. Government must establish the evaluation and supervision mechanism of environmental accounting information disclosure and the Quality Standard of Environmental Accounting Information Disclosure of Heavy Pollution Industry, so as to provide operable legal basis for the society and the audit supervision of environmental accounting information disclosure of coal and other heavy pollution industries. Government must enforce environmental pollution reporting system and to authorize the Ministry of Environmental Protection to formulate mandatory and binding policies on information disclosure for industries with high pollution emissions.

- From the perspectives of enterprises: enterprises must enhance the awareness of environmental accounting information disclosure, consciously abide by environmental protection laws, regulations and relevant policies. Enterprises must concern more about the collection of environmental accounting elements and information disclosure so as to provide reliable information for the supervision by the whole society. Enterprises must improve the supervision and accountability of environmental accounting information. While urging enterprises to implement the commitment of environmental protection measures, government should require enterprises to implement the financial input and output of these commitments in financial reports, such as accounting statements one by one. Moreover, the accounting department of enterprises should establish the accountability system of environmental accounting information disclosure. Therefore, government should build the disclosure system of enterprise's environmental accounting information in terms of disclosure policy, supervision mechanism and reporting system. Enterprises should disclose environmental accounting information more comprehensively and systematically, so as to improve their profitability and development ability, and realize the win-win situation of environmental and economic interests.

\section{References}

[1] Huang Changjiao. Exploration on the content and form of environmental accounting information disclosure [J]. Accounting research, 2013(1): 26- 28.

[2] Belkaoui A. The impact of the disclosure of the environmental effects of organizational behavior on the market [J].Financial Management, 1976, 5(4): 26-31.

[3] Botosan C, Plumlee M. Are Information Attributes Priced, Unpublished paper, University of Utah, 2007.

[4] Montabon F, Sroufe R, Narasimhan R. An examination of corporate reporting, environmental management, practices and firm performance [J]. Journal of Operations Management, 2007 , 25(5): 998-1014

[5] U Kalu, G U Aliagha, A Buang.A Review of Economic Factors Influencing Voluntary Carbon Disclosure in the Property Sector of Developing Economies [C]. IOP Conference Series: Earth and Environmental Science, 2015

[6] Kothari S P, Shu S, Wysocki P D. Do Managers withhold Bad News? Journal of Accounting Research, 2009 (1)

[7] Wen Subin, Zhou Liuliu. The impact mechanism of corporate carbon information disclosure on financial performance the "inverted U" moderating effect of media Governance [J]. Management review, 2017, 29 (11): 183-193

[8] Cai Feijun, Chai Xiaoying. Research on the conduction effect of environmental information disclosure on financial performance [J]. Accounting journal, 2017 (25): 5-8

[9] Liu Jinbin, Yang Wenwu. Research on the relationship between enterprise environmental accounting information disclosure and financial performance - a case study of Listed Companies in Sichuan Province [J]. Business accounting, 2018 (16): 4-8

[10] Lu Ming, Qian Hongguang. Empirical Study on the impact of environmental information disclosure on financial performance of Listed Companies [J]. Audit monthly, 2016 (5): 48-51

[11] Dai Yue, Shi mengge. The impact of corporate environmental information disclosure on financial performance: Empirical Evidence from Listed Companies in heavily polluted industries [J]. Financial studies, 2015 (1): 71-75 
[12] Ni Juan, Kong Lingwen: environmental information disclosure, bank credit decision-making and debt financing cost: Empirical Evidence from Listed Companies in heavily polluted industries in Shanghai and Shenzhen stock exchanges [J]. Economic review, 2016 (01): 147-156

[13] Yang Yang. Research on the impact of environmental accounting information disclosure on performance of Listed Companies in pollution intensive industries [D]. Xi'an: Xi'an University of science and technology, 2016

[14] Ma Ming, Qian Guangming, Ji Yu. Empirical Study on the relationship between environmental information disclosure and financial performance of manufacturing enterprises [D]. Journal of Liaoning University of petroleum and chemical technology, 2019 (3): 98-102

[15] Lu Bei, Li Yanan. The relationship between environmental information disclosure and enterprise value from the perspective of system management [J]. Journal of systems science, 2020, 28 (5): $123-127$

[16] Fu Haoyue, Wang Junhui. Research on Influencing Factors of environmental information disclosure of listed companies: Empirical Evidence from 100 heavy polluting enterprises [J]. Contemporary economic science, 2011, 33 (4): 115-123

[17] Wang Xiaohong, Wang Haimin, Li Binquan. Research on the influence domain of environmental accounting information disclosure of listed companies: a case study of Listed Companies in Shaanxi Province [J]. Contemporary economic science, 2011, 33 (4): 115-123

[18] Zheng Chunmei, Xiang Chun. Research on the influencing factors of environmental information disclosure of Listed Companies in China: An Empirical Study Based on 170 listed companies in Shanghai Stock Exchange [J]. Science and technology progress and countermeasures, 2013, 12 (6): 98-102

[19] Zhong huaizhen. Empirical Study on the correlation between enterprise environmental accounting information disclosure level and performance management - Taking the panel data of 80 listed companies in heavy pollution industries as an example [J]. Financial and accounting communication, 2016 (03): 83-86

[20] Wei Xiaobo. Peng Jue. Empirical Study on Impacts of Environmental Regulation on Environmental Information Disclosure of Listed Companies of China: Based on Researches of Listed Companies in Nonferrous Metal Industry[J]. Canadian Social Science, 2012(10): 113-123 